\title{
LETTER FROM A CITIZEN OF THE SOUTHERN CONFEDERACY
}

Berkeley Co., Virginia, Southern Confederacy, The 12, May, 1861.

Dear Brother, Samuel Thatcher:

I seat myself this Sabbath morning to answer your kind letter which I. received last week, and to let you know that I and my family are all well; hoping that you and yours are enjoying the same great blessing.

I have not written to you concerning the death of my wife, she died on the first of March, 1860, lasted but 46 hours, leaving me, 6 sons and one daughter to mourn her loss. My sister-in-law Adaline Miller, has kept house, and she lived with' ts 2 years before the death of my wife and she is still with us. You wrote to me that there was a great excitement in your state concerning national affairs. "Now the crisis is only an artificial one; when I look out I see nothing going" wrong, there's nobody hurt." 'This was the language of Abraham Lincoln, that was elected for to be president of the Great United States of America. It now appears to me that the man Abram or Abraham begins to think that something is going wrong and altho, he has at this time thirty thousand soldiers around him to guard him and the capital, he is still afraid of the southern rebels as he calls them, that they will hurt somebody. Well now I will let you know as near as I can how the eall of Abram Lincoln was responded to here. He called for 75 thousand volunteers to crush the Rebels in the Seceded States. I was at Harper's Ferry yesterday and learned that Virginia has at this time 76 thousand Volunteers under arms and well equipped and will. resist with their lives and fortunes and their sacred honor, any Northern Army that Lineoln may send against them.

\footnotetext{
${ }^{1}$ This letter, written by J. W. Thatcher, of Virginia, to his brother, Samuel Thatcher, of:Ohio, reflects the intense feeling that frequently divided families along the border states during the Rebellion. It came into the possession of the late V. P. Twombly, and was by him turned over to the Historical Department.-Editor.
} 
Berkeley County furnished six large companies and they are at Harpers Ferry; there are five thousand troops at Harpers Ferry at this time. Mry oldest son belongs to the Berkeley Cavalry; he left home last Friday three weeks ago, he is only, 17 years of age, but is very near as large as I am.

Hardly one family around here, but some one, two, or" three, of its number have gone to defend the rights of the south; we may be over run, but may not be easily subdued. I believe the only way the Federal Government can conquer the South will be to exterminate them, sweep them from the face of the earth. We begged long and hard for the Crittenden Compromise, which if it had been granted, would have saved the Border States and been no loss to the North. They wouldn't give us that. Then we wanted to separate in peace and they won't let us go that way; and I tell you now brother, the first blood that the northern troops shed on Virginia soil will be the beginning of a contest such as was never seen this side of the Atlantic. I was one of the number that went to Harpers Ferry from Martinsburg the time of the John Brown raid, which was on Monday, the 17th of October, 1859 , and I there seen the teachings of the North, and if it could have been carried out, where would we have been? The Sharps rifles and pistols and pikes some two or three thousand in number, the pikes with long handles; they were handed to the slaves that they took, but they could not be persuaded to use them against their masters, where did these instruments come from? There must have been a large number of men in the North aiding in this irrepressible conflict, the 22 men that came there could not have made all those instruments themselves and kept it a secret. But, I am now glad that John Brown did come to Harpers Ferry, that very affair give the South warning and she prepared herself for: the coming conflict.

If what the Northern Journals say comes true, then our lands, after we are murdered, will be given to the Northern soldiers for their pay.

Now brother I have written to you and have not been writing fictitious language; you asked me to let you know how things stood, and I have this to say to you about this war, 
that if the Black Republican Government at Washington is as determined as we are, then I say to you goodbye.

Now I will ask of you to write to me and let me know low it stands out there, give me a full account, etc.

I remain your brother and well wisher,

J. W. Thatcher.

P. S. I have 75 acres of wheat and 25 acres of barley which I sowed last fall and it looks very well.

I sowed 20 acres of oats this spring and have planted 25 acres of corn, and 25 acres to plant yet, just half done.

I have one hundred and twenty-four head of sheep at this time, I sold 7 head last week for 31 dollars after I. sheared them.

I. have 11 head of hogs and 34 head of eattle.

I am farming besides my own land, which is 343 acres, my sister-in-law's and brother-in-law's 260 acres which is over 600 acres, and you may juige whether I. have much time to jdle away.

J. W. Thatcher to Samuel Thatcher.

My best love to you and Emily.

The Fourth of July was celebrated in this city most agreeably: A large procession of citizens, headed by the city band, after parading the streets, marched to the courthouse where the Declaration of Independence was read by Warner Lewis, Esq., and an oration delivered by George Greene, Esq.; after which about 200 citizens (including ladies) sat down to a dinner prepared by Mr. Fanning on the ground in tront of the courthouse.-Dubuque, Iowa Transcript, July 12, 1844. (In the newspaper collection of the Historical Department of Iowa.)

'That Buffalo.

There will be a shooting match at Dudley on Christmas day next-first match for the Buffalo. Ye Knights of the Rifle he on hand; much sport may be expected. So clean up those old guns and pick your flints.-Fort Des Moines Star, November $23 ; 1849$.' (In' the newspaper collection of 'the Historical Department of Towa.) 
Copyright of Annals of Iowa is the property of State of Iowa, by \& through the State Historical Society of Iowa and its content may not be copied or emailed to multiple sites or posted to a listserv without the copyright holder's express written permission. However, users may print, download, or email articles for individual use. 